\title{
Weaving colourful threads: A tapestry of spirituality and mysticism
}

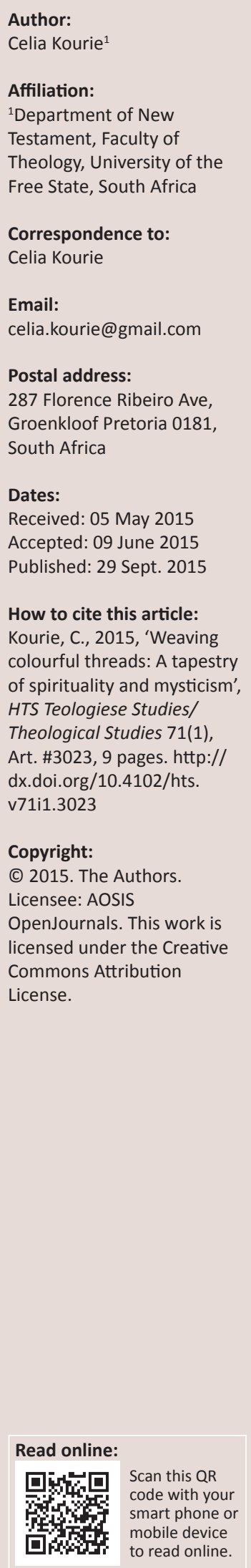

Given the plethora of research conducted in the field of spirituality and mysticism over the last 30 years, it is almost a superhuman feat to keep up with the explosion of information. Of necessity, in a limited article of this nature, it is possible to discuss only a few salient aspects of the spirituality and mysticism phenomenon and by so doing contribute to ongoing research in this important domain. Contemporary spiritualties encompass the whole range of human experience and new variants are emerging; for example, the relatively recent Contemplative Studies, a cognate and close companion to Spirituality. Crossing inter-religious boundaries enhances studies in Mysticism; natural mysticism is clearly in the foreground; and breaking research in neurotheology sheds light on the nature of the 'mystical mind'. Discussion of the value or otherwise of techniques and methods of the mystical journey continues unabated. Of great value for today's frenetic, Internet-crazy world is the path of mystical silence. By contributing to a discussion of these issues, it is hoped that the threads of spirituality and mysticism will continue to share their colour in a world desperate for beauty and peace.

\section{Introduction}

There is no doubt that the 'tapestry' of spirituality comprises many diverse strands; it is nigh impossible to keep up with the vast array of material that has been woven over the last 30 years or so. The information explosion via the Internet adds to the plethora of data that confronts us on a daily basis. ${ }^{1}$ Given this reality, new insights and new patterns of spirituality are constantly coming to the fore, and for this reason there is always room for further exploration and understanding of this exciting phenomenon. In addition, the global consciousness of the present era, together with the inter-religious and interspiritual ambience of the 21st century witnesses to the fact that former attitudes of isolation, hostility, domination and colonialism are giving way to respect and openness to the wide variety of spiritual traditions and mystical experience. Our pluralistic society exhibits openness to the 'other', resulting in greater cross-cultural understanding and tolerance for diversity - much needed in today's world. The essential contextuality of spirituality and mysticism is to be found within the parameters of a given society, and therefore cannot be examined in a vacuum. This is not to say, however, that diverse spiritualities are necessarily bound to their specific culture. On the contrary, many traditions break away from established cultural and sociological frameworks and contribute to an ever-expanding diversity and understanding of spirituality and mysticism. This can be seen in the explosion of diverse spiritualities in contemporary society, many of which are not affiliated to any religion. In fact, 'spirituality' is to be found in all sectors of society, and the term itself has become something of a 'catch-phrase'. It has been described as an 'applause-word'2 and is widely used in medicine, business, education, art, ecology, social studies, political discourse, et cetera, to mention but a few areas. In the public arena spirituality focuses on pragmatic concerns, and can be a force for individual and societal progress. Against this background, the aim of this article is as follows: firstly, to discuss certain strands of the tapestry of spirituality and mysticism; and secondly, by so doing, illustrate their heterogeneity and value in our postmodern world. Of necessity, this is only a limited selection, given the plethora of strands that are woven in the field of spirituality and mysticism today.

\section{The nature of spirituality}

Given the vast array of literature in the field of spirituality, with the equally large number of current and emerging issues, the following is not a taxonomy of the latter, but rather a brief reflection on a few salient aspects, namely: forms; definition; authentic and inauthentic spirituality; interpretation; academic teaching; transformation; and contemporary spiritualities, in particular the emerging field of Contemplative Studies. Of necessity, there is a certain overlap between some of these facets of spirituality.

1. A Google search for 'spirituality' yields 151 million entries.

2. Spirituality is the 'kind of word that is no sooner uttered than everyone breaks out in applause' (Carson 1994:381). 
Contemporary culture witnesses to many forms of spirituality:

[...] eclectic, evanescent, unfocused, vaguely religious, fragmented, fleeting, dilettante spiritualities [...] conservative, world-denying spiritualities [...] liberal spiritualities, new ageisms and 'occultures' that colonise and package Oriental practices for Western audiences. (Finnegan 2008:41) $)^{3}$

In addition, spiritual traditions manifest a wide variety of expression; diverse types will appeal to different personalities; for example, more extrovert spiritualities which deal with concrete issues of practical life; contemplative, or introvert spiritualities, which concentrate more on the inner life; and integrated spiritualities, combining both facets. Societal spirituality would ideally combine orthopraxis with orthokardia so as to implement an embodied practice. Perhaps we can speak of a certain 'malleability' with respect to the domain of spirituality, so as to accommodate the vast differences of temperament and inclination of human beings; not to mention the fact that spiritualities are culture-specific bringing manifold richness of expression into play.

Spirituality refers to the deepest dimension of the person and has been defined, amongst other things, as a 'way of ego-transcending transformation' (Finnegan 2008:23); 'selftranscendence toward the ultimate value one perceives' (Schneiders 1986:266; 2003:165); 'our relation to the Absolute' (Waaijman 2002:1). Further insights with respect to defining spirituality can be gleaned by revisiting the work of one of the pioneers in the field of spirituality, Walter Principe. ${ }^{4}$ Principe $(1983: 136,139)$ suggested that in order to understand spirituality one must keep in mind three levels of enquiry: firstly, the 'existential' or 'real' level, namely the lived reality; secondly, the teaching about this lived reality; and thirdly, the scholarly investigation of the first and second levels. Principe's (1983) definition of spirituality encompasses two aspects, namely general and particular:

Spirituality [...] points to those aspects of a person's living faith or commitment that concern [...] striving to attain the highest ideal or goal. For a Christian, this would mean [...] striving for an ever more intense union with the Father, through Jesus Christ by living in the Spirit. (p. 139; cf. Wiseman 2006:6-7)

Spirituality, therefore, refers to the raison d'être of our existence, the meaning and values to which we ascribe. In this sense, everyone embodies a spirituality in the wider sense of the term; it can be nihilistic, materialistic, humanistic, or religious. Its referents can just as much be power, success,

\footnotetext{
3.Spirituality (Stringfellow 1984:19, cited in Perrin 2007:16) may connote: "[S]toic 3.Spirituality (Stringfellow 1984:19, cited in Perrin 2007:16) may connote: '[S] toic
attitudes, occult phenomena, the practice of so-called mind control, yoga discipline, attitudes, occult phenomena, the practice of so-called mind control, yoga discipline,
escapist fantasies, interior journeys, an appreciation of Eastern religions, multifarious
pietistic exercises, superstitious imaginations, intensive journals, dynamic muscle pietistic exercises, superstitious imaginations, intensive journals, dynamic muscle tension, assorted dietary regimens, meditation, jogging cults, monastic rigors,
mortification of the flesh, wilderness sojourns, political resistance, contemplation, abstinence, hospitality, a vocation of poverty, non-violence, silence, the efforts of prayer, obedience, generosity, exhibiting stigmata, entering solitude, or I suppose among these and many other things, squatting on top of a pillar'. Whilst some of the above may be 'tongue in cheek', nevertheless Stringfellow's appraisal witnesses to the broad spectrum of diverse practices in contemporary society in an effort to express the inner spiritual dimension of the human being.

4.The late Walter Principe was a Catholic priest and Professor at the Pontifical Institute of Medieval Studies, Toronto. His area of expertise was historical theology, spirituality and Christology. He was also a former President of the Catholic Theological Society of America. His 1983 article, Toward Defining Spirituality, has Theological Society of America. His 1983 article, Toward Defining Spirituality, has
become a classic for students of spirituality. See also Principe's Spirituality, Christian become a classic for stude
(Downey 1993:931-938).
}

money, sex, pleasure, or a way of life oriented around an ultimate reality and meaning which transcends egoorientation (Griffin 1988:1). Spirituality is an 'innate human characteristic'; the human spirit is 'human consciousness, a constitutive (fundamental) dimension' of being human (Perrin 2007:20, 21). Therefore, it is a reality that we all share:

Spirituality, whether or not it is linked to a belief in God, struggles with the mystery of the deep questions around the meaning of human life. The human spirit remains open to the search for authentic truth within the varied experiences of life, establishes normative values, exercises reasoned judgment, and involves the entire human being on the path to self-determination'. (Perrin 2007:20)

With respect to authentic and inauthentic spirituality, Perrin's (2007:24) observation is worth noting, namely the fact that not all spiritualities are life-giving and in fact can be harmful: 'Human spirit is not absolutely benevolent. Without careful attention, it can be led astray, resulting in destructive and harmful human actions' (Perrin 2007:24). Authentic spirituality is characterised by a positive expression of 'self-liberating transcendence [...] directed toward the common good of humanity', whereas 'clusters of values, actions and choice, such as alcoholism, Nazism, or consumerism [...] have mistaken the quest of the human spirit and cannot be considered authentic expressions of spirituality'. ${ }^{5}$

Furthermore, spirituality today is often marketed as 'product'; this needs careful discernment on the part of the spiritual seeker, as 'Spiritual counsel, books, and paraphernalia are sold as offering quick-fixes to modern problems [...] Spirituality is in many instances a consumer product, and it sells' (Perrin 2007:24). Caution is needed, therefore, in assessing contemporary elements of spirituality:

People need to be critical (in the sense of careful and thoughtful) of current trends in spirituality, whether they are associated with a religious belief system or not. Taking the attitude that when it comes to spirituality, everything goes, is simply not responsible [...] Spirituality can be benevolent or destructive. Some critical understanding is needed so that people can assess what to encourage and to discourage. (Perrin 2007:25)

Methods of interpretation are numerous: 'The difficulty is that spirituality is interpreted through theistic, transpersonal, naturalistic, mainstream, minority, esoteric, contemplative, mystical, transcendental, secular, agnostic, atheistic, or monistic lenses' (Finnegan 2008:270). This witnesses to the desire of contemporary women and men to find their own meaning in life and espousing an autogenic spirituality. There is what Tacey (2004:4) calls 'the spirituality revolution', which involves 'a democratization of the spirit'; it is about 'individuals taking authority into their own hands, and refusing to be told what to think or believe'. It relates to

5.Schneiders (2005a:2) contends that 'negative patterns such as alcoholism or consumerism [...] do not constitute a spirituality'. However, it could be argued consumerism [...] do not constitute a spirituality. However, it could be argued that although on's spiritual path can unfortunately be expressed in a negative manner, this does not detract from the essential spiritual nature of the person, and therefore, everyone embodies some kind of spirituality. Perrin (2007:17) refers to the mass-murder-and-suicide of about 900 people, at Jonestown in 1978, as a clear example of 'non-authentic' spirituality. 
personal autonomy; finding the Divine in ordinary life; jettisoning ties with organised religion; rejecting autocratic systems of religion and dogmatic intransigence; relinquishing entrenched beliefs, myopic values and patriarchal systems of leadership and fundamentalism. Tacey (2003) cogently elaborates on these issues:

Spirituality and fundamentalism are at opposite ends of the cultural spectrum. Spirituality seeks a sensitive, contemplative relationship with the sacred and is able to sustain levels of uncertainty in its quest because respect for mystery is paramount. Fundamentalism seeks certainty, fixed answers and absolutism, as a fearful response to the complexity of the world and to our vulnerability as creatures in a mysterious universe. (p. 11)

Furthermore, fundamentalism, which is often prevalent in the monotheistic faiths, is a 'full-blown regression, a deliberate and systematic retreat from the demands and revolutions of the modern period' in order 'to escape the tensions and complexities of a difficult present' (Tacey 2004:5). On the other hand, authentic spirituality resists rigid dichotomies and inflexible presuppositions; exhibits a 'tolerance for ambiguity'; and as a result, has in many cases experienced 'opprobrium from more traditional institutions' (Van Ness 1996:4). In spite of the fact that many established religious institutions consider the resurgence of spirituality as dangerous, heretical and a threat to their survival, others point to a rapprochement between spirituality and religion (cf. Schneiders 2003).

Academic courses in the field of spirituality are in great demand. A detailed investigation of issues regarding the academic study of spirituality has been dealt with elsewhere (Kourie 2009). Suffice it here to touch on two pertinent issues. Firstly, the question as to how spirituality should be taught. McGinn (2005a:38) admits that he is not sure 'that spirituality needs a separate niche in the curriculum in order to be adequately assimilated' and whilst programmes in spirituality certainly have a function, so as to give spirituality 'the voice it deserves [they] need not be taken as the only way to achieve the goal'. This viewpoint is a current issue of debate in academic circles. Given the interdisciplinary nature of spirituality studies, it could be argued that it be integrated into other disciplines. In many instances, this is already the case. Waaijman (2011:2; cf. Waaijman 2007:1-113) delineates several areas of research where spirituality is now studied academically outside the field of theology. Such research is conducted not only in areas which have variously given attention to spirituality, such as literature, linguistics, philosophy, and religious studies, but also within a far broader spectrum, including medicine, psychology, sociology, management and education. As it is conceded that spirituality impacts every aspect of life, is there a need for a separate discipline? My answer to this question is in the affirmative, particularly given the fact that spirituality is a relatively new discipline in today's academic ambience. It has had to argue the case for its existence, in certain cases, and therefore, it is best at this stage to maintain its own 'niche' in the academy. ${ }^{6}$ A second issue relates to the participative or self-implicating nature of academic studies in spirituality, and the transformative potential of the research itself. Many students who engage in intellectual study are already involved in some practice of spirituality, or are contemplating some personal forays into the realm of lived spirituality. The question could be posed as to whether personal involvement could be a stumbling block to objective and critical study. BurtonChristie (2005:103) argues against this position: 'one's love of the subject, far from being a hindrance to careful academic work, constitutes an initial and enduring interpretive key, informing our work at every step along the way'. ${ }^{7}$ In addition, the transformative nature of the process is very often a continuing incentive during the research journey. This journey can take the following form:

[...] moving from an initial naiveté, where the love of the subject is all, to a more critical perspective, in which the subject 'comes apart' as it were into its component elements, to a post-critical 'second naiveté' where one is able to reintegrate what has been pulled apart in the critical process, [and] reengage the subject matter deeply and thoughtfully. (Burton-Christie 2005:103) ${ }^{8}$

The transformation effected at this level can be experienced at both a personal and societal level, '[a]s Socrates knew, one cannot wrestle with ultimate truth without becoming a different person' (Schneiders 2005b:31). This effects involvement in the midst of everyday activity, be it political, social, economic, et cetera, '[i]nteraction, participation, and active citizenship thus should be seen as forms of spiritual practice' (Sheldrake 2005:290). Consequently, study of spirituality forms the basis for apostolic service and societal transformation. Van Aalsum (2013:263), drawing on the magum opus of Waaijman (2002), illustrates the importance of morality in teaching spirituality: 'If we as educators [...] succeed in stimulating [...] awareness of the divine-human relationship, we give [...] a gift for life that is invaluable'. As a consequence, students are provided not only with 'moral knowledge', but also, such spirituality nourishes their 'moral consciousness' (Van Aalsum 2013:263).

6.The introduction of the 'new' discipline of Spirituality into the 'revered corridors of higher education', thus giving it university status, has not been without controversy from those within the established disciplines, in particular that of theology and religion (Kourie 2009:148). Particularly, in the early stages of implementation of the discipline, the Academy has, in some instances, been the 'Nemesis for Experience': 'Experience is sometimes a red flag to universities, who [...] want to be scientific. Theological scholars typically fear the surrender of revelation to subjective Theological scholars typicalties [..] have experiences [...] Other faculties [...] have grave doubts about securing critical distance for such an experientially loaded field [...] [however] it is [...] possible that the uneasiness with experience is the death rattle of old university annexations and world' (Kourie \& Ruthenberg 2009:194-195). See also Kourie (2010:17-31) for an account of the implementation of Christian Spirituality degree progammes at Unisa, Pretoria, South Africa.

7.Experience of teaching spirituality for many years confirms Burton-Christie's (2005) position. In addition, the personal involvement of students in the subject helps them along the often arduous path of research, especially at Masters and Doctoral level.

8.Burton-Christie (2005:103-107) gives as an example of this journey his own criticalparticipative approach to a desert hermeneutic. Moving away from a 'literalistpropositional' reading of Scripture, he was 'exhilarated at discovering an approach to Scripture at once attentive to the beauty and power of language and aimed to Scripture at once attentive to the beauty and power of language and aimed unabashedly at the religious transformation of the reader/hearer/proclaimer'. This, together with his forays into rigorous historical-criticism at Oxford University led to a rapprochement between historical endeavour and personal commitment. Hence his appreciation for both critical distance and reengagement led him to the conclusion that 'only by investing ourselves completely - both imaginatively and critically - will the subject we so love yield its secrets in deepened understanding and appreciation (cf. Flanagan 2015). 
As we consider the manifold threads of the web of spirituality, we cannot but be amazed by the plethora of contemporary spiritualities that continue to grow at an astounding rate. An analysis of these would be a Sisyphean task and is outside the purview of the present work. ${ }^{9}$ Suffice it to offer a few brief comments on an emerging discipline in the field of spirituality, namely, Contemplative Studies, a cognate field to that of Christian Spirituality. It has come into being over the last decade or so, and is still in an 'embryonic phase', working in similar areas to that of Christian Spirituality. Whilst a 'fellow-traveller' with the latter, its distinctive charism is the 'human practice and cultivation of contemplative states, events, and ways of life' (Sherman 2014:209). With respect to the meaning of the term 'contemplation', it is 'taken largely as a term of art indicating a state of subjective expansion, deep concentration, wonder, tranquility, illumination, or communion' (Sherman 2014:209). In similar vein to its sister discipline, Christian Spirituality, the field of Contemplative Studies is interdisciplinary, with special attention given to biomedical and therapeutic fields. Bearing in mind that contemplative practice is currently utilised in a wide sector of society, the results of 'contemplative, meditative and mindfulness practices' in society witness to their beneficial nature. However, as with Christian Spirituality, the scholarly endeavours of this emerging field are equally concerned with 'not only [...] third-person studies of their topic, but [with] the cognitive and transformative value of first-person contemplative inquiry, as well' (Sherman 2014:211). Clearly, this new development is to be welcomed and both theoreticians and practitioners of Christian Spirituality will no doubt find many areas of collaborative research and engagement in future. $^{10}$

Given the analysis of the aforementioned issues in spirituality, it has to be conceded that this is of necessity a lacunary synopsis of recent research. Nevertheless, it witnesses to the ongoing and in-depth scholarly investigation that continues unabatedly in this field. Given the nature of this enterprise, it would indicate that spirituality is here to stay, and that ever-deepening insights into its nature, function and manifold expressions will certainly continue to engage scholars as to what it means to be human.

A second and closely related cluster of issues bears upon the related field of mysticism to which we now turn.

\footnotetext{
9.A short selection would include, amongst others, women's spirituality; men's spirituality; ecospirituality; atheistic spirituality; sexuality and spirituality; art and spirituality; ecospirituality; atheistic spirituality; sexuality and spirituality; art and spirituality; interspirituality; business and spirituality; health care and spirituality; technology and spirituality; global spirituality; gay and lesbian spirituality; new age technology and spirituality; global spirituality; gay and lesbian spirituality; new age
spirituality; cities and spirituality; psychology and spirituality; work and spirituality, and biblical spirituality. See, with respect to the latter, the recent contribution to this subdiscipline: De Villiers, Kourie and Lombaard (2006); De Villiers and Pieterson (2011); and De Villiers (2013). The articles in these publications flow from conferences on Biblical Spirituality at Radboud University, Nijmegen, the Netherlands; University of Gloucestershire, UK and the Carmelite Institute, Malta initiated by Prof. Pieter de Villiers, Professor Extraordinarius in Biblical Spirituality, at the University of the Free State, Bloemfontein South Africa. There has definitely been a sea-change of considerable magnitude regarding academic interest in a spiritua or mystical interpretation of scripture (Kourie 2011: cf. Sherman 2014:227 fn 12 where he lists a number of references dealing with this important development in hermeneutics).
}

10.The Inaugural International Symposia for Contemplative Studies took place in 2012. The emerging field has developed specific groups, particularly within the American Academy of Religion; with organisations such as the Mind and Life Institute and the Association for Contemplative Mind in Higher Education. It has several research centres and graduate programs at American Universities (Sherman 2014:208)

\section{Mysticism}

Of necessity, in dealing with the mystical threads of our tapestry, it is nigh impossible to avoid a certain superficiality and over-simplification of the complex phenomena involved. Any examination of the phenomenon of mysticism brings certain questions to the fore, questions that continue to fuel debate amongst philosophers, religionists, theologians and other interested parties. ${ }^{11}$ There is no easy, unequivocal definition that does justice to the full range of issues involved in the study of mysticism, so what is offered below is merely a preliminary and heuristic notion of mysticism. It is hoped that this endeavour will illustrate true mysticism and by so doing expose any ersatz manifestations of this phenomenon. By way of a preliminary conclusion, it is my contention that mysticism is the acme of the spiritual path - not in the sense of a linear development - but as the intrinsic telos of the human being. In the light of the foregoing, brief reflections are now offered, amongst others, on the following aspects of mysticism: definition; types; epiphenomena; neuropsychiatry; neurotheology; and the way of silence.

Carmody and Carmody (1996) offer the following as a working description of mysticism: 'direct experience of ultimate reality'; they continue:

'Ultimate reality' can connote 'God', 'the Tao', 'nirvana', 'the sacred', or any of the other terms [...] coined to indicate what is unconditioned, independent of anything else, most existent, dependable, valuable [...] This is a working definition. It is a model, a template, a hypothesis to get us going. (pp. 10-11)

The immediacy of such contact stresses the 'ultimacy of what the mystic meets or is touched by' and emphasises 'the experiential character and the directness of mysticism', together with 'the ineffable aspect' of the mystical encounter (Carmody \& Carmody 1996:13). ${ }^{12}$ Mysticism can be seen as a 'canvas upon which the soul paints in the wilderness of the heart its passionate return to Source' (Lanzetta 2001:16). Further:

[...] the core of mysticism is the radical surrender of self to the loving embrace of the Other who is at the foundation of all life, the One to whom we owe our very existence. (Perrin 2005:443)

11.Amongst others, the questions of essentialist versus empirical or constructivist interpretation of mysticism; these and other theoretical aspects of mysticism have been discussed in an earlier article (Kourie 1992); for example, mystical experiences, as they are recorded in the mystical texts, portray the fact that they are embedded within certain ideological, cultural and linguistic constructs. Does this totally preclude a pure experience, which does not involve conceptualisation this totally preclude a pure experience, which does not involve conceptualisation,
but is a formless experience free from mind-dependent inferences? See Marshall but is a formless experience free from mind-dependent inferences? See Marshall
(2005:167-203), where he discusses the continuing debate between proponents of 'pure consciousness' and the 'constructivist/contextualist' paradigm; Carmody and Carmody (1996:6-9) who illustrate the differences between the Essentialists and the Empiricists; and Karuvelil (2010:259-275) in his discussion of mysticism language and truth. Whilst constructivist arguments cannot be dismissed, nevertheless, it can be argued that the deep structures of consciousness are relatively a-historical, collective and cross-cultural, whereas surface structures are variable, historically conditioned and culturally formed. The limitations of the 'socio-cultural' or 'socio-deterministic' model must be acknowledged, whilst at the same time acknowledging its value (cf. Kruger 2006:255-259).

12.Carmody and Carmody (1996:13) refer to Parmenides, whose exclamation 'Is!' sums up the reality of 'pure existence' or pure actuality, with respect to the mystical experience. They also refer to possible cognates in other traditions, for example, Lao-tzu, and certain Jewish and Christian mystics, who, utilising Exodus $3: 14$, are brought to the directness of the divine name. 
Waaijman (2002) defines mysticism as:

[...] a relational process between God and man [sic], a process which has its own language and logic [...] the intimacy of mystical love purifies the intellect, the will and the memory until they are completely attuned to God. (p. 357)

McGinn (2008:47; cf. McGinn 2011), drawing on the work of Lonergan and Merton, speaks of mystical consciousness as 'meta-concsciousness' - a consciousness beyond - which is 'the co-presence of God in our inner acts, not as an object to be understood or grasped, but as the transforming Other'.

With special reference to Christian mysticism, earlier studies held it to be 'a special state of consciousness surpassing ordinary experience through union with the transcendent reality of God' (Wiseman 2006:9), with the result that mysticism was seen as an extraordinary experience, one not easily available to all. However, in recent decades, there has been a democratisation of mysticism, which makes it applicable to ordinary life and accessible to all as quotidian mysticism. One could say that each one is a mystic, or a mystic 'in embryo'; it is no longer reserved for a spiritual elite, namely monks, nuns, hermits, et cetera. This insight regarding the nature of mysticism is applicable to adherents of diverse religions, or to those who do not adhere to a particular religious tradition. A recent contribution to the discussion of the nature of Christian mysticism is the suggestion that the term presence is better than 'union', particularly if the latter is seen as loss of self in a state of absorption with the divine. As a result:

[...] the mystical element in Christianity is that part of its belief and practices that concerns the preparation for, the consciousness of, and the reaction to what can be described as the immediate or direct presence of God. (McGinn 1991:xvi, vii)

However, it also needs to be emphasised that, '[s]ince God cannot be present the way a created thing in the universe is present, many mystics insist that a true consciousness of God is best realised by absence' (McGinn 2005b:19). This is a recurring theme in mystical literature and is illustrated in negation and apophasis 'a process of negation that strips away all experiences, images and concepts to aim toward the mystery that lies beyond both affirmation and negation' (McGinn 2005b:19).

In his description of patristic and early medieval approaches to mystical theology, McIntosh (2005) notes that they witness to 'unveilings' that are:

$[\ldots]$ an ordinary part of a divinely given cosmos in which the whole creation echoes with a divine self expression that is radiant beyond the the capacity of creatures to declare - except by pointing beyond themselves to a hidden presence. (p. 455)

By imbibing the language and teaching of this divine presence, believers are equipped 'to pass over into the radiance of divine truth' (McIntosh 2005:455). The paradox of 'hiddenness' and 'radiance' illustrates the limitations of language in its attempt to describe what is essentially ineffable. It is necessary to 'transcend' language by engaging one's faculty of intuition in order to grasp the hidden meaning of the mystical statement. Just as distortions of grammar and syntax are the means by which the poet tries to convey something that cannot be encompassed by ordinary language, paradox is used to describe the inexpressible.

The consciousness of this 'source'; 'union with the divine'; or the 'ground of being'; or 'ultimate reality' will vary, depending on the type of mysticism under investigation, and whether its predilections are theistic or monistic. As mentioned above, definitions of mysticism, in many cases, are closely determined by a particular religious or cultural stance; for example, certain religious traditions emphasise the ontological difference between God and creature, whereas other religious systems, particularly the wisdom traditions of the east, propagate an elimination of the subject or object polarity. Introvertive mysticism may be characterised by an inner realisation of peace; the oneness of all reality; emptiness - entering the void; or pure consciousness. On the other hand, extrovertive mysticism is often experienced in nature mysticism, which is not necessarily religious, but exhibits feelings of wonder, bliss and rapport with creation. In addition to the foregoing, the mystical experience can effect a realisation of panentheism, namely the reality of the divine in the beauty of the natural world, experienced, amongst others, as 'transcendence of space and time [...] expansive joy and bliss [...] intuitive insight into the workings of the universe, luminosity, wonder and beauty' (Parsons 2005:458). Natural mysticism can also be experienced in the reality of daily life: nature, music, literature, art, childbirth, distress, sex, anaesthetics, et cetera, can be triggers for a mystical experience, some leading to transcendent illuminative insight, and others to a more natural extrovertive mysticism (Borchert 1994:27). Given the prevalence of experiences such as the foregoing, deracinated from church allegiance and religious ideation, there has been an increasing appreciation for nonreligious mystical experience. ${ }^{13}$ Furthermore, such occurrences put paid to the view that mystical experience is normally an indication of an advanced spiritual life. The results of such experiences are often life-changing: 'Increased contentment, peace, happiness, a sense of perspective, deepened love, empathy, tolerance, forgiveness, no fear of death and the importance of love' are some of the consequences of this mystical spirituality (Marshall 2005:106).

Having described mysticism as 'the yearning of the human spirit for utmost transcendence' Kruger (2006) speaks of certain varieties of what he calls 'tasting the silence':

There are forms of mysticism that are feelings of devotion to God or Nature or Universe, or suffering because of being distant from that ultimate source. And there are forms that have a marked quality of intuitive, intellectual (in the old, more than rational, sense of the word) understanding about them. (p. 9)

13.Various explanations have been offered to explain nature mysticism: 'Freud's developmental notion of the regression to primary narcissism, the Self psychologist Heinz Kohut's concept of a developmentally mature cosmic narcissism, Heinz Kohut's concept of a developmentally mature cosmic narcissism,
neuropsychological concepts involving temporal lobe and parietal lobe functions, and various metaphysical and transpersonal theories' (Parsons 2005:460). 
Certain extraordinary features may accompany the mystical state, particularly at the beginning of the mystical journey. These epiphenomena, such as trance, ecstasy, visions, locutions, et cetera, reported by mystics across diverse traditions, are acknowledged, but seen as passing facets of mysticism, which should not be sought after for their own sake. ${ }^{14}$ Some of these experiences are often due to the physical repercussions of the infusion of contemplation, and generally cease once the human organism has been purified and strengthened. Furthermore, even mystics who experience extraordinary phenomena have argued that 'such things were secondary to the deep inner consciousness and love of God that could not be seen but was manifested in a more loving life' (McGinn 2012:35-36).

Relativisation of mystical epiphenomena, with concomitant detachment from spiritual gifts and renunciation of psychic powers is a sound test of authentic mysticism. Therefore:

While accounts of visions of God and the heavenly world, descriptions of ecstatic states, even stories about paranormal gifts, are part of the mystical tradition, they are peripheral rather than central. This is why many mystics insist that God can and should be found in ordinary, everyday consciousness as an awareness of the divine depth in all things. (McGinn 2012:35) ${ }^{15}$

Appreciation of mysticism and its value can be found by many who do not report any notable experience themselves: The well-known 20th century psychologist and philosopher, William James ([1902] 1982), is worth quoting here:

I have no living sense of commerce with a God. I envy those who have, for I know that the addition of such a sense would help me greatly. The Divine, for my active life, is limited to impersonal and abstract concepts, which, as ideals, interest and determine me, but do so but faintly in comparison what a feeling of God might effect, if I had one. Yet, there is something in me which makes response when I hear utterances from that quarter made by others. I recognise the deeper voice [...] Call this, if you like, my mystical germ. (p. xxiv) $)^{16}$

Roy (2003:xxi), whilst acknowledging diverse levels of consciousness, particularly in the light of recent neurotheological studies, nevertheless prefers to see mystical consciousness as 'a permanent state, a basic disposition, a stable mood [... which] requires cultivation, that is, moral

14.See Borchert (1994:47-66) for an analysis of ecstasy, visions, apparitions, et cetera. His analysis includes the example of Emmanuel Swedenborg (1688-1772) who 'found the partition between the physical and the spiritual world so transparent that seeing spirits was hardly different from seeing humans. He made contact with spirits [...] and used this ability to obtain a great deal of information about th spirit world. The results were published in a bulky treatise, The Arcana Coelestia' Borchert (1994:60) comments on the negative appraisal of Swedenborg by Kant, which contributed to a 'tide of opinion against mysticism, but [...] did nothing to stop a growing interest in its accidental phenomena'. See Yungblut (1979:74-87) for his appraisal of the Vagaries and Aberrations of the Mystical Way, and in particular his recommendation that depth-psychological insights can be useful in avoiding 'certain forms of self-deception' and distinguishing between 'psychic phenomena and capacity for extrasensory perception, on the one hand, and authentic mystical experience on the other'.

15.Other types of 'extra-ordinary psychical experiences' can include 'philosophical', 'creative', 'aesthetic' and 'elemental' which 'overlap with the mystical' (Kruger 2006:9). Whether these experiences are particularly 'extra-ordinary' or even 'psychical', is questionable, and would need further elaboration.

16.See James ([1902] 1982:379-429) for an in-depth analysis of mysticism, in particular his well-known 'marks' of mystical experience, namely ineffability; noetic quality; transiency and passivity. asceticism as well as the practice of meditation' ${ }^{17}$ Closely allied to the foregoing is the field of consciousness studies, and its links with the mystical, inter alia, the relationship of psychiatry and mysticism. A greater understanding of the nature of mysticism on the part of both the therapist and the client effects greater appreciation of its value for patient care; for example, both psychosis and mystical experience can lead to perceptual changes; however, the effects differ. Greater integration is generally a result of the latter; whilst in psychosis, increasing fragmentation and confusion are experienced. A more accurate appraisal of the mystical experience enables health professionals better understand this difference. Neuropsychiatric research of this nature validates the benefits of mysticism from a neurological perspective (Drazenovich \& Kourie 2009:2, 7). ${ }^{18}$

D'Aquili and Newberg (1999:14) suggest that 'mystical experiences are generally regarded as the mechanism by which a human being can enter into the realm of God or Ultimate Reality, depending on the particular religion'. Within a neurophysiological investigation, various altered states of consciousness are analysed, in order to analyse the 'possible neurophysiological mechanisms' underpinning the mystical states (D'Aquili \& Newberg 1999:110). Focusing on the state of 'absolute unitary being' (AUB), which is 'the state in which the subject loses all awareness of discrete limited being and of the passage of time, and even experiences an obliteration of the self-other dichotomy', both passive and active approaches are investigated (D'Aquili \& Newberg 1999:119-110). The passive approach involves 'simply trying to clear one's mind of all thoughts' whereas the active approach focuses on an object, be it 'an image, a figure, a person, a sound or a word' (D'Aquili \& Newberg 1999:110). Analysis of brain activity during such meditative states is instrumental in the effort to understand or at least describe mystical experiences from a neurophysiological perspective.

Further analysis of this scientific research is outside the ambit of the present discussion; suffice it to say that it opens the door to fascinating explorations in the field of neurotheology, and deserves ongoing reflection. It is worth noting certain caveats regarding this research, given by the authors themselves:

The reader should be cautioned against using this model in too reductionist a way. Even if subsequent testing with PET scanning and similar procedures should support the model [...] it still raises significant neuroepistemological problems. To maintain that the reality of people's 'objective' experience of God is reducible to neurochemical flux, and nothing more, may be equivalent to maintaining that their experience of the 'objective' reality of the sun, the earth, the air they breathe is reducible to neurochemical flux. (D'Aquili \& Newberg 1999:120)

17.Roy (2003:xx) concentrates on trophotropic as opposed to ergotropic states, the former are characterised by 'low levels of physiological and cognitive activity or nourishing"; cf. D'Aquili and Newberg (1999:25-26), who distinguish between the Hyperquiescent State and the Hyperarousal State. In addition, the former, 'with eruption of the arousal system'; and the latter, 'with eruption of the quiescent system', indicate that these states can sometimes function in a complementary protective antagonistic [inhibitory] mechanism' (D'Aquili \& Newberg 1999:24).

18.See Shea (2005:49-54) for an evaluation of the role of spirituality in different psychological and psychotherapeutic modalities. 
Furthermore, the aforementioned research illustrates the problem concerning the very nature of subjectivity, objectivity, and consciousness. Therefore naïve reductionism, which would trivialise the ontological status of mystical states, is to be avoided:

We are only now embarking upon a scientific investigation of some of the most powerful experiences humans can attain. Thus, we should maintain an attitude of humility, rather than presume that our understanding of neurophysiology can give us an intrinsic knowledge of the relationship between 'reality' and consciousness. (D'Aquili \& Newberg 1999:120)

The value of empirical studies in brain and consciousness research is clearly inestimable. However, the participants in the experiments described above are practitioners of meditation, and normally comprise a small percentage of the population. For a vast majority of people, the mystical reality is elusive. Why is this so? Are we no longer developmentally adequate to this disclosure? Have our mystical faculties become atrophied? This may well be the case, particularly in our technologically dominated Western society, with social media demanding almost 24-hour attention. However, it is my contention that the potential for mysticism is innate; for this potential to flower it is necessary to relinquish the view that sense perceptions are the sole criteria for knowledge of the universe. In order to move from the exterior to the interior, from the peripheral and marginal to that which is central and essential, there has to be a pacification of the senses. The mind has to become free from its reactive patterns and emotional fog so that the deep structures of consciousness may become the locus of mystical disclosure. This may well call for a path of purification and transformation of consciousness in order to effect what could be called a divine 'osmosis'.

Evelyn Underhill ([1914] 1986:52), the well-known mystic and theoretician of mysticism, writing at the end of World War II, describes the beginning of the mystical process in a succinct and direct manner: 'The education of the mystical sense begins in self-simplification. The feeling, willing, seeing self is to move from the various and the analytic to the simple and the synthetic'. Progress and growth, including exterior and interior purification in order to set aside attachment to what is transitory, form a conceptual dynamic in the mystical way. By way of a preliminary observation, it can be said that mystical techniques, particularly meditation, may help harness the mind as it progresses through the various gradients in the journey towards mystical integration. Of course, objections can be levelled against any form of ascesis and following rigid and artificial schemes. A 'method-less method' or 'techniqueless technique' sets aside all psychological and physical strictures and promotes living truly in the present moment and the perpetual flux of reality. There is certainly merit in such an approach, whilst at the same time, the value of ascesis cannot be denied, provided it does not become an end in itself. A further point to bear in mind is the fact that emotions such as 'love, beauty, wonder [and] grief' may be the catalyst for the 'simplifying act' (Underhill [1914] 1986:54). No one technique or 'non-technique' can be seen to be the definitive means by which the individual enters into the emptiness of unconditional awareness. Bearing in mind the aforementioned caveat, the following section will offer a few reflections on the way of silence.

\section{The way of silence}

As noted above, the varieties of mysticism have been described as diverse ways of 'tasting the silence' (Kruger 2006:9). One illustration of this 'way' or 'path' has been expressed as follows: 'Spirit is Itself, knows Itself, enjoys Itself. But it does so through and in a relative "other": not any "other" outside itself, but inside Itself' (Kruger 2006:75). Therefore, the 'mystical way is the way back to Spirit, of the droplet back to the ocean, realizing that It was never left' (Kruger 2006:76). External confusion and distraction constantly impact negatively on the human person. Therefore, silence and solitude are essential in order to effect unification and integration in the depths of the personality. They are generative of psychological integration and personal wholeness. Although at face value, a passive quality, silence is nevertheless the fountainhead of a fundamental dynamism. Silence is only possible where there is a void, an inner emptiness. Lacout (1985:13) describes the stages of silence in terms of the progress of the individual in love, '[s]ilence and love go hand in hand. The quality of the one indicates the quality of the other'. An inner state of equilibrium and peace can be maintained even in the midst of external noise and activity. Such a silence, vivid and intense, is both exterior and interior, existing through and within the ceaseless round of human activity, and results in a new poise, and the cultivation of the interior 'ground' of one's being. This includes living in pure spontaneity of love and utter poverty; a 'fasting mind' or 'no-mind' results not in vacuity, but rather in 'full emptiness'. Thus, the ascesis of silence does not necessarily mean material separation from external things, but a solitude of spirit, which facilitates a mystical modality of life. ${ }^{19}$

\section{Silence of the mind brings total peace:}

Silence is the complete cessation of all mental activities leading to the total dissipation of the unconscious layer. Consequently, there is a state of pure consciousness, a peace that is boundless, ineffable, transcendental and bubbling with infinite potentialities. The state of pure consciousness is everything. It is the energy that becomes the whole existence [...] The whole of the mystical or spiritual science is based on silencing the mind [...] From silence is born the whole existence. In silence it exists and to silence it will go back [...] The harmony of existence is due to an ineffable silence. (Paramananda 2011:88-89)

19.A modern mystic, Dag Hammarskjold (1964:16), former Secretary-General of the United Nations, in his well-known work, Markings, speaks of the process of accepting silence: 'When all becomes silent around you, and you recoil in terror - see that your work has become a flight from suffering and responsibility, your unselfishness your work has become a flight from suffering and responsibility, your unselfishness a thinly disguised masochism; hear, throbbing within you, the spiteful cruel heart of the steppe wolf - do not then anaesthetize yourself by once again calling up the shouts and horns of the hunt, but gaze steadfastly at the vision until you have plumbed its depth"; (cf. 1964:108): 'the "mystical experience". Always: here and now - in that freedom which is one with distance in that stillness which is bor of silence [...] a freedom in the midst of action, a stillness in the midst of other human beings'. See also, lyer (2014) for an evaluation of silence from the pen of a contemporary travel journalist. 
This silence-event cuts across all religious, ethnic, linguistic, cultural or conceptual traditions - it is pure consciousness. It is expressed in diverse ways in various traditions, for example:

There the eyes go not; speech goes not, nor the mind,

We know not, we understand not,

How could one teach it.

Where from words turn back,

Together with the mind, not having attained. (Taitariya

Upanisad, II.4.9, cited in Vineeth 2009:11)

In like manner, the practice of zazen, sitting meditation, in Zen Buddhism, emphasises the role of silence in order to experience formlessness, detachment, emptiness and receptivity. Silence results in steadiness, calm, and tranquillity. Such contemplative silence is a profound form of attention, seeing with the eyes of the spirit, an attitude of adherence to inner realities, entering into a space that surpasses all boundaries. Once discursive thought has been silenced and attentiveness fills one's consciousness, true living in the present moment is possible.

The mystical insight of Kabir clearly exemplifies the unknowability of the Divine. His poetry expressed the fact that God cannot be articulated. Kabir turns language upside down, and breaks down 'the conventional barriers between the concretely everyday and the transcendent [...] deflating all metaphysical abstractions' (Kruger 2006:246). This is clearly reflected in his poetry. Whilst describing God as 'the breath of all breath' nevertheless, nothing can be said about the divine Reality:

O how may I express that secret word?

O how can I say He is not like this, and He is like that? [...]

He is neither manifest nor hidden.

He is neither revealed nor unrevealed:

There are no words to tell that which He is. (Kruger 2006:246)

Underhill ([1911] 1995) indicates that such a:

[...] state of 'Quiet' entails suspension of the surfaceconsciousness [...] the external world seems to get further and further away [...] [this state] is as a nothingness, a pure passivity, an emptiness. (p. 318)

As silence becomes more profound, mystical consciousness becomes apophatic, as there is a realisation that language is ontologically impoverished and unable to capture the reality of the Other in words. Therefore, as pseudo-Dionysius states, the mystic plunges into:

[...] the truly mysterious darkness of unknowing. Here, renouncing all that the mind can conceive, wrapped entirely in the intangible and the invisible [...] he knows beyond the mind by knowing nothing. ${ }^{20}$ (cited in Fanning 2001:36)

The further one ascends to God, the more 'as we plunge into that darkness which is beyond intellect, we shall find

20.Quotations are from Pseudo-Dionysius. The Complete Works (cited in Fanning 2001:36). ourselves not simply running short of words but actually speechless and unknowing' (cited in Fanning 2001:36). Apophasis shatters all conceptual forms and linguistic constructs which risk the domestication of the divine. This can be seen as an epistemological shift, which allows for nonlinguistic reality; the security of language is attenuated and eventually all conceptual forms disappear. Yet, at the same time, 'the absence of human speech [...] the silence of ineffability is a tool for positive knowledge beyond conscious cognition' (McGlynn 2011:194).

Whilst the way of the mystic may well include ascetical methods, by which the senses are purified, nevertheless, the way of silence is seen to be of paramount importance. Inner silence leads to a rich emptiness. We can speak of an epistemological shift which allows for nonlinguistic reality; the security of language is attenuated and eventually all conceptual forms disappear. Vivid and intense, such silence exists through and within the ceaseless round of human activity. It is a silence which is the root of sound and intensifies rather than attenuates communication. It is not empty, not a solipsistic journey or quietist apathy, but on the contrary a 'loving attention' - an entry into a space surpassing all boundaries, effecting a state of peace which is then actualised in daily life.

\section{Conclusion}

The tapestry of spirituality and mysticism manifests interrelated strands woven in multitudinous patterns, by which meaning and significance can be given to 21st century living. The multiplicity of contemporary spiritualities and the desire for mystical reality witness to a current longing for access to the transcendent; a desire to live life in depth; and a dissatisfaction with dogmatic and prescriptive directives which no longer speak to women and men today. Freed from older deterministic frames, true religion is no longer dependent for its actualisation upon rigid theological systems. Authentic spirituality, with its concomitant societal concern, illustrates the need for an engaged commitment for the factuality of human experience in all areas of the human endeavour, not only in moments of beauty and wonder, but also in times of monotony and opaqueness. A contemplative spirituality, which is open to the mystical, manifests a greater sense of wonder and awe in the natural world. Whilst appreciative of the many advances in science and technology that contribute to an improvement of lifestyle, especially for the most impoverished, mystical spirituality works against the tyranny of scientific materialism and selfishness so prevalent in today's frenetic and secularist society. Advances in neurotheology illustrate that deep states of silence have a beneficial impact on the human system, and show that meditation taps into the deep energies and structures of the psyche, effecting a release of psychospiritual power. This could be described as an active infusion of Infinite Spirit into finite spirit, or perhaps more accurately, an awakening to the inner actualisation of the same. Therefore, mystics can be seen as paradigms of human authenticity; in many cases they are pioneers shedding light on what is hidden and pointing to a 
passionate encounter with the Divine. Mystical fruits can be seen in their warmth of love; in self-giving; in often dynamic qualities of leadership, expressed in the bent for action; in the faculty for adapting and re-adapting oneself to circumstances and discernment of what is possible and what is not; and in a spirit of simplicity which triumphs over complications, in a word, supreme good sense. Finally, in the words of a mystical aphorism: 'It is here! It is here!'

\section{Acknowledgements Competing interests}

The author declares that she has no financial or personal relationships which may have inappropriately influenced her in writing this article.

\section{References}

Borchert, B., 1994, Mysticism. Its history and challenge, Samuel Weiser, Maine.

Burton-Christie, D., 2005, 'The cost of interpretation: Sacred texts and ascetic practice in desert spirituality', in E. Dreyer \& M. Burrows (eds.), Finding the spirit. The study of Christian spirituality, pp. 100-107, The Johns Hopkins University Press, Baltimore MD.

Carmody, D.L. \& Carmody, J.T., 1996, Mysticism: Holiness East and West, Oxford University Press, Oxford.

Carson, D.A., 1994, 'When is spirituality spiritual? Reflections on some problems of definition', Journal of the Evangelical Theological Society 37(3), 381-394.

D’Aquili, E. \& Newberg, A., 1999, The mystical mind: Probing the biology of religious experience, Fortress, Minneapolis, MN.

De Villiers, P.G.R., 2013, 'The spirit that guides. Discernment in the Bible and spirituality', Acta Theologica Supplementum 17, 1-291.

De Villiers, P.G.R., Kourie, C.E.T. \& Lombaard, C., 2006, 'The spirit that moves. Orientation and issues in spirituality', Acta Theologica Supplementum 8, $1-196$.

De Villiers, P.G.R. \& Pieterson, L.K., 2011, 'The spirit that inspires. Perspectives on biblical spirituality', Acta Theologica Supplementum 15, 1-219.

Drazenovich, G. \& Kourie, C., 2009, 'Mysticism and mental health: A critical dialogue', HTS Teologiese Studies/Theological Studies 66(2) Art. \#845, 8 pages. http://dx.doi. org/10.4102/hts.v66i2.845

Fanning, S., 2001, Mystics of the Christian tradition, Routledge, London.

Finnegan, J., 2008, The audacity of spirit. The meaning and shaping of spirituality today, Veritas, Dublin.

Flanagan, B., 2015, 'Research as spiritual practice', viewed 03 April 2015, from http:// spirasa.org/2015/01/25/bernadette-flanagan-on-teaching-spirituality

Griffin, D.R., 1988, Spirituality and society: Postmodern visions, State University of New York Press, New York, NY.

Hammarskjold, D., 1964, Marking, Faber \& Faber, London.

Iyer, P., 2014, The art of stillness. Adventures in going nowhere, Simon and Schuster, London.

James, W., [1902] 1982, The varieties of religious experience, Penguin, New York, NY.

Karuvelil, G., 2010, 'Mysticism, language and truth', Journal of Dharma 35(3), 259-275.

Kourie, C., 1992, 'Mysticism: A survey of recent issues', Journal for the Study of Religion 5(2), 83-103.

Kourie, C., 2009, 'Spirituality and the university', Verbum et Ecclesia 30(1), 148-173.

Kourie, C., 2010, 'Teaching spirituality at Unisa, 2000-2010: Some reflections', Missionalia 38(1), 17-31.

Kourie, C., 2011, 'Reading Scripture through a mystical lens', in P.G.R. de Villiers \& L.K. Pieterson (eds.), The spirit that inspires. Perspectives on biblical spirituality. Acta Theologica, Supplementum 15, 132-148.

Kourie, C. \& Ruthenberg, T., 2009, 'Experience: Its significance in contemporary Christian spirituality', in J. Smit \& D. Chetty (eds.), Alternation. Religion and diversity. Journal for the Study of the Arts and Humanities in Southern Africa, 177-198, CSSALL, Durban.

Kruger, J.S., 2006, Sounding unsound. Orientation into mysticism, Aurora, Pretoria.

Lacout, P., 1985, God is silence, Quaker Home Service, London.

Lanzetta, B., 2001, The other side of nothingness. Toward a theology of radical openess, State University of New York Press, New York, NY.
Marshall, P., 2005, Mystical encounters with the natural world: Experiences and explanations, Oxford University Press, Oxford.

McGinn, B., 1991, The foundations of mysticism. Origins to the fifth century, vol. 1, The Presence of God, A History of Western Christian Mysticism, SCM, London.

McGinn, B., 2005a, 'The letter and the spirit. Spirituality as an academic discipline', in E. Dreyer \& M. Burrows (eds.), Minding the spirit. The study of Christian spirituality, pp. 25-41, The Johns Hopkins University Press, Baltimore.

McGinn, B., 2005b, 'Mysticism', in P. Sheldrake (ed.), The new SCM dictionary of Christian spirituality, pp. 19-25, SCM, London.

McGinn, B., 2008, 'Mystical consciousness: A modest proposal', Spiritus: A Journal of Christian Spirituality 8(1), 44-63. http://dx.doi.org/10.1353/scs.0.0012

McGinn, B., 2011, 'Mysticism yesterday, today, tomorrow: The intersection of the timeless with time', Tattva 3(1), 1-13.

McGinn, B., 2012, 'The mystical tradition', in R. Woods \& P. Tyler (eds.), The Bloomsbury guide to Christian spirituality, pp. 30-41, Bloomsbury, London.

McGlynn, M., 2011, 'Silence and ineffability as cognition in San Juan de la Cruz' Coplas Del Mismo Hechas Sobre Un Éxtasis de Alta Contemplación', Studies in Spirituality 21 193-217. http://dx.oi.org/10.2143/SIS.21.0.2141950

McIntosh, M., 2005, 'Mystical theology', in P. Sheldrake (ed.), The new SCM dictionary of Christian spirituality, pp. 445-456, SCM, London.

Paramananda, S., 2011, 'Mystics are beyond religions', Tattva 3(1), 88-89.

Parsons, W., 2005, 'Nature mysticism', in P. Sheldrake (ed.), The new SCM dictionary of Christian spirituality, pp. 458-460, SCM, London.

Perrin, D., 2005, 'Mysticism', in A. Holder (ed.), The Blackwell companion to Christian spirituality, pp. 442-457, Oxford University Press, Oxford.

Perrin, D., 2007, Studying Christian spirituality, Routledge, London.

Principe, W., 1983, 'Toward defining spirituality', Studies in Religion/Sciences Religieuses 12, 127-141. http://dx.doi.org/10.1177/000842988301200201

Principe, W., 1993, 'Spirituality, Christian', in M. Downey (ed.), The new dictionary of Catholic spirituality, pp. 931-938, The Liturgical Press, Minnesota, MN.

Roy, L., 2003, Mystical consciousness: Western perspectives and dialogue with Japanese thinkers, State University of New York Press, New York, NY.

Schneiders, S., 1986, 'Theology and spirituality: Strangers, rivals or partners?', Horizons 13(2), 253-274. http://dx.doi.org/10.1017/\$036096690003632X

Schneiders, S., 2003, 'Religion vs. spirituality: A contemporary conundrum', Spiritus: A Journal of Christian Spirituality 3(2), 163-185. http://dx.doi.org/10.1353/ scs.2003.0040

Schneiders, S., 2005a, 'Christian spirituality: Definition, method and types', in P. Sheldrake (ed.), The new SCM dictionary of Christian spirituality, pp. 1-6, SCM, London.

Schneiders, S., 2005b, 'Approaches to the study of Christian spirituality', in A. Holder (ed.), The Blackwell companion to Christian spirituality, pp. 15-33, Blackwell, Oxford.

Shea, J., 2005, 'Spirituality, psychology and psychotherapy', in P. Sheldrake (ed.), The new SCM dictionary of Christian spirituality, pp. 49-54, SCM, London.

Sheldrake, P., 2005, 'Christian spirituality as a way of living publicly. A dialectic of the mystical and prophetic', in E. Dreyer \& M. Burrows (eds.), Minding the spirit. The study of Christian spirituality, pp. 282-297, The Johns Hopkins University Press, Baltimore, MD.

Sherman, J.H., 2014, 'On the emerging field of contemplative studies and its relationship to the study of spirituality', Spiritus: A Journal of Christian Spirituality 14(2), 208-229. http://dx.doi.org/10.1353/scs.2014.0031

Stringfellow, W., 1984, The politics of spirituality, John Knox, London.

Tacey, D., 2003, 'Rising waters of the spirit', Studies in Spirituality 13, 11-30. http:// dx.doi.org/10.2143/SIS.13.0.504586

Tacey, D., 2004, The spirituality revolution. The emergence of contemporary spirituality, Routledge, London.

Underhill, E., [1914] 1986, Practical mysticism, Ariel, Columbus, OH.

Underhill, E., [1911] 1995, Mysticism. The development of humankind's spiritual consciousness, Bracken, London.

Van Aalsum, L., 2013, 'Spirituality in education and the twofold schooling of the teacher. An exploration based on the study "spirituality" by Kees Waaijman', Studies in Spirituality 23, 251-276. http://dx.doi.org/10.2143/SIS.23.0.3007320",

Van Ness, P. (ed.), 1996, Spirituality and the secular quest, SCM, London.

Vineeth, F., 2009, 'In search of the ineffable', in S. Chackalackal (ed.), New horizons of Indian living. A festschrift in honour of Prof. Dr. Vadakethala Francis Vineeth CMI, pp. 5-36, Vidyavanam, Bengaluru.

Waaijman, K., 2002, Spirituality. Forms, foundations, methods, Peeters, Leuven.

Waaijman, K., 2007, 'Spirituality - A multifaceted phenomenon. Interdisciplinary explorations', Studies in Spirituality 17, 1-113. http://dx.doi.org/10.2143/ explorations', Studie
SIS.17.0.2024643

Waaijman, K., 2011, 'Spirituality as theology', Studies in Spirituality 21, 1-43.

Wiseman, J., 2006, Spirituality and mysticism: A global view, Orbis, New York, NY.

Yungblut, J.R., 1979, Discovering God within, Element, Rockport, MA. 